\title{
軸受鋼のリング壓懐値につデて
}

(軸 受鋼の研究 II)

(昭和 28 年 4 月本会潇演大会にて講演)

出口喜勇 爾*

\section{ON THE RING CRUSHING TEST OF THE BALL BEARING STEEL}

(Study on the Ball Bearing Steel II)

Kiyoji Deguchi

\section{Synopsis:}

(1) To substitute the bend fracture test of flat test pieces (flat $10^{\circ} \times 20 \times$ length $55 \mathrm{~mm}$, distance between the two supporting points $40 \mathrm{~mm}$ ) at the place of ring crushing test (standard size of rings: outer dia. $80 \times$ inner dia $60 \times$ height $20 \mathrm{~mm}$ ) of the ball bearing steels, the author studied experimentally the relation between the crushing strength $P$ and the bend fracture strength $Q$, measuring the both in parallel, changing the quenching and tempering temperatures; with the ring and flat test pieces, both shaped out and forged. (2) Then the author calculated the relation equation between $P$ and $Q$, considering the test pieces as the perfect elastic body. From the idea that the test pieces broke when the max. tensile skin stress on the section "at the loading point increased beyond the strength of this material, the author obtained

$$
P / Q \doteqdot 0.806 \boldsymbol{\alpha}
$$

From the idea that the test pieces broke when the deformation energy on the section at the loading point increased beyoad a limit value, the author obtained

$$
\mathrm{P} / \mathrm{Q} \fallingdotseq 0.890 x^{\prime}
$$

where $\alpha$ and $\alpha^{\prime}$ were the coefficients which were determined according with their manufacturing conditions, for example, fibre direction etc. (3) Next the author determined the values and $\boldsymbol{\alpha}^{\prime}$ so that these theoretical equations accommodated well with the values practically measured. Considering the statiatically measured results of the forged test pieces from the production billets of about 110 charges, rather than the test resulte of the several charges above mentioned in (1), the author obtained $\alpha=0.85$. and $\alpha^{\prime}=0.75$. Then $P \fallingdotseq 0.6763 \mathrm{Q}$ : so, when $P=4,000 \mathrm{~kg}, \mathrm{Q} \fallingdotseq 6,000 \mathrm{~kg}$. By these data, the author proposed: to substitute, the bend fracture test of flat test pieces in place of ring crushing test and to define that the bend fracture strength must be more than $6,000 \mathrm{~kg}$. (1) The author checked the coefficient $\alpha$ by means of the resistance wire type strain gauge. (5) The author checked the relations between the size of rings and their crushing strengths theoretically obtained, comparing with the values practically measured. (7) At last, the autbor studied the influences of rolling or forging conditions of the billets etc. on their ring crushing strengths.

\section{I. 緒言}

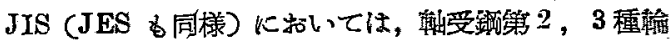
・材に垡しロングの圧壊試験を規定している，即「供試材

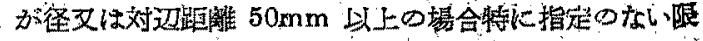

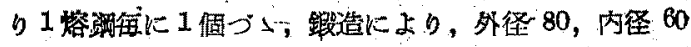

* 日本特殊鋏株式會社 


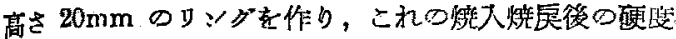

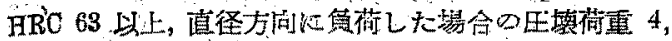

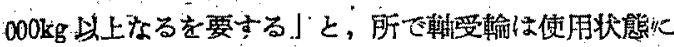

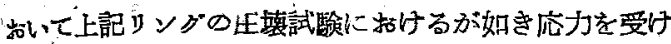

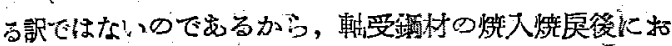

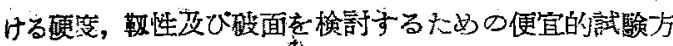

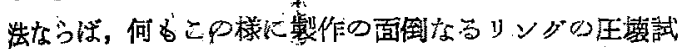

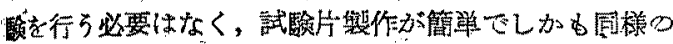

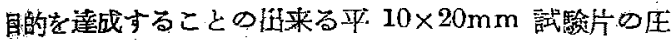

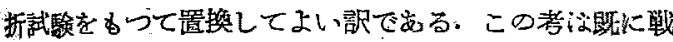

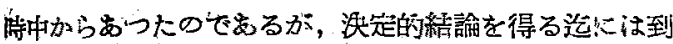

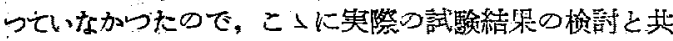

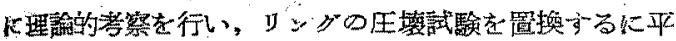

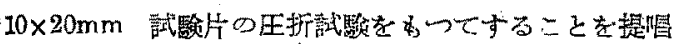
งる.

\section{II. 試 驗 方 法}

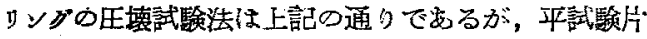

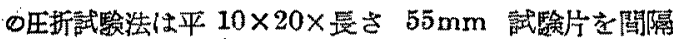
$40 \mathrm{~mm}$ の丽支点にて支光，乙の中央部に洛いてこれに 垂直に先端丸み $\mathrm{R}=1 \mathrm{~mm}$ のステムで静的に加乐し圧折 するとをの荷重を測定する. 平 $10 \times 20 \mathrm{~mm}$ としたのは その断面積をリングすそれと等しくするためである。掄

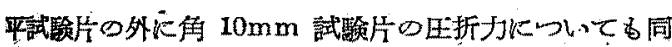

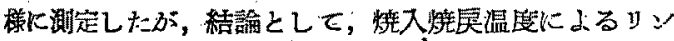

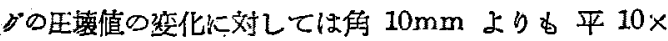
$20 \mathrm{~mm}$ 試験片の方が一層平行した贸化傾间を示すので，

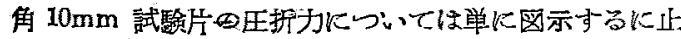
める。

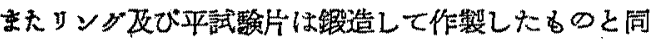

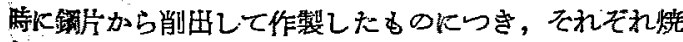

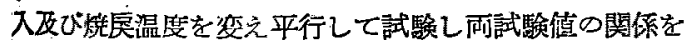
求め，現埸製品につてを䖻計的に比酸し，これらに対

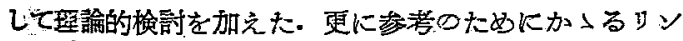

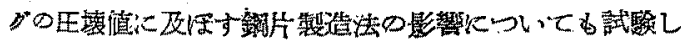
t:

\section{III. 試料}

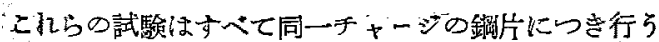
のが锂想的であるが，試験が相当長年月にわたつて行わ

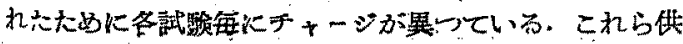

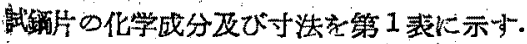

\section{IV. リングの㗨壤値と平試験片の 座所カとの關保}

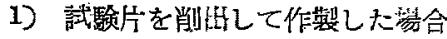

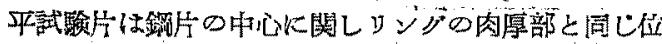

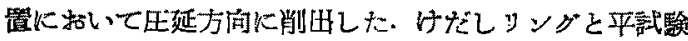

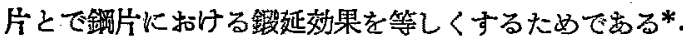

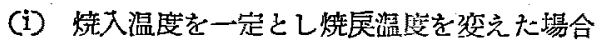

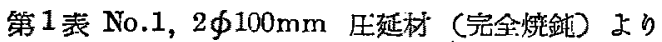

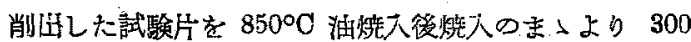

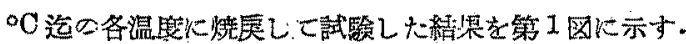

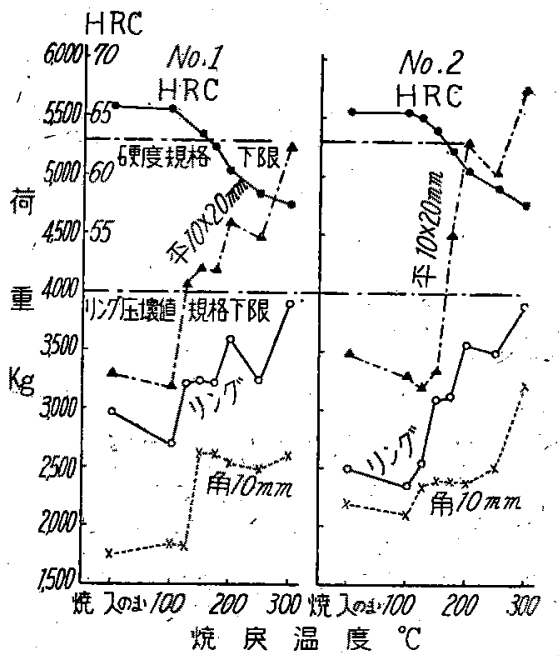

筒，1，路

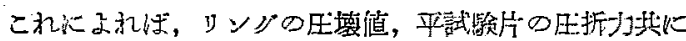

*これに関し次の様な試験結果がある, 即次記成分の $\phi 185 \mathrm{~mm}$ 压延材（完全焼針）につき，周緑部，半

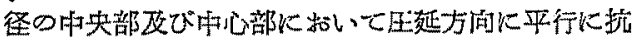

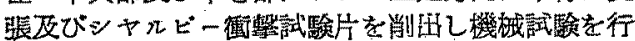
らたところ下表の通りであらた。

\begin{tabular}{|c|c|c|c|c|c|}
\hline $\mathrm{O}$ & $\mathrm{Si}$ & $\mathrm{Mn}$ & $P$ & $\mathrm{~S}$ & $\mathrm{Or}_{\mathrm{r}}$ \\
\hline 0.96 & $0 \cdot 26$ & $0: 42$ & 0.029 & 0.015 & $1 \cdot 61$ \\
\hline 位 监 & $\begin{array}{l}\text { 绦伏點 } \\
\mathrm{kg} / \mathrm{mm}^{2}\end{array}$ & 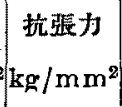 & 伸\% 胶\% & $\mid \begin{array}{c}P+\pi r \\
-\underset{k g m}{/ \mathrm{cm}^{2}}\end{array}$ & $\begin{array}{l}\text { ブ } \\
\star \approx n\end{array}$ \\
\hline 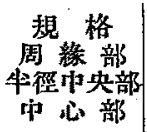 & $\begin{array}{l}40 \cdot 8 \\
\mathbf{3 8} \cdot 3 \\
\mathbf{3 7} \cdot 7\end{array}$ & $\begin{array}{c}<75 \\
68: 0 \\
67 \cdot 5 \\
65 \cdot 2\end{array}$ & $\mid$\begin{tabular}{l|l}
$>25$ & \\
$28 \cdot 6$ & $56 \cdot 8$ \\
$28 \cdot 2$ & $48 \cdot 0$ \\
$23 \cdot 2$ & $38 \cdot 3$
\end{tabular} & $\begin{array}{l}6 \cdot 1 \\
6 \cdot 1 \\
6 \cdot 2\end{array}$ & $\begin{array}{r}<201 \\
197 \\
192 \\
187\end{array}$ \\
\hline
\end{tabular}

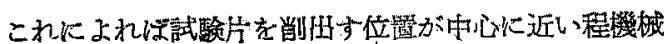
的性算特に絞が相当低い值を示す，影微鈿組識を見ると 周縁部に比し中心部の方が Slag, 粗大炭化物多く且孷

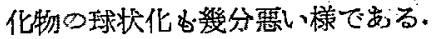




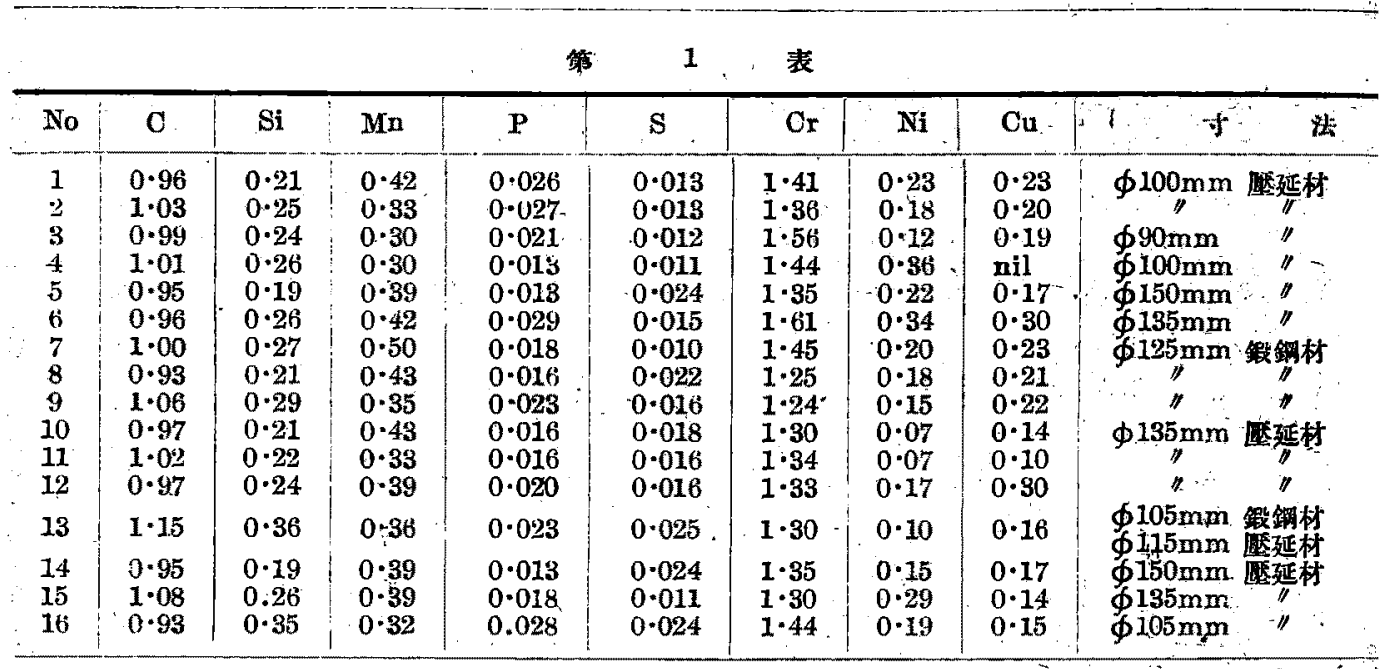

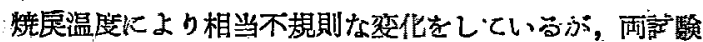
值は比輍的平行に变化している. なたれら両試淤ては

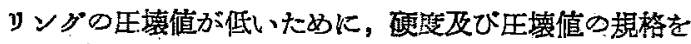
間特に满足すべき焙戻温度は存在しない。

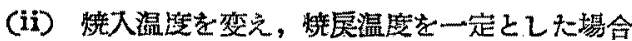

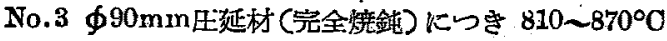
間て抽焼入後すへて $150^{\circ} \mathrm{C}$ 㜔戻して試験した結果第 2 図に示す。これによれば，硬度は $840^{\circ} \mathrm{C}$ 迄は暁入湿 度と共に上界するぶこれ以上では殆を゙变化なく、リング

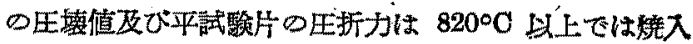

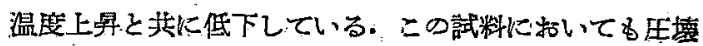

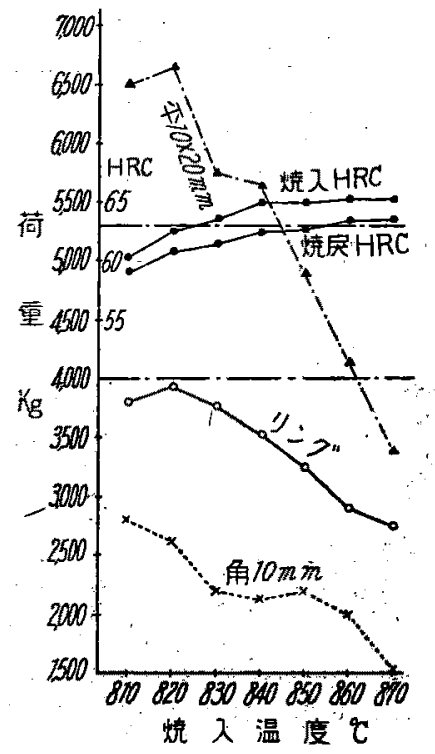

第 2 圆

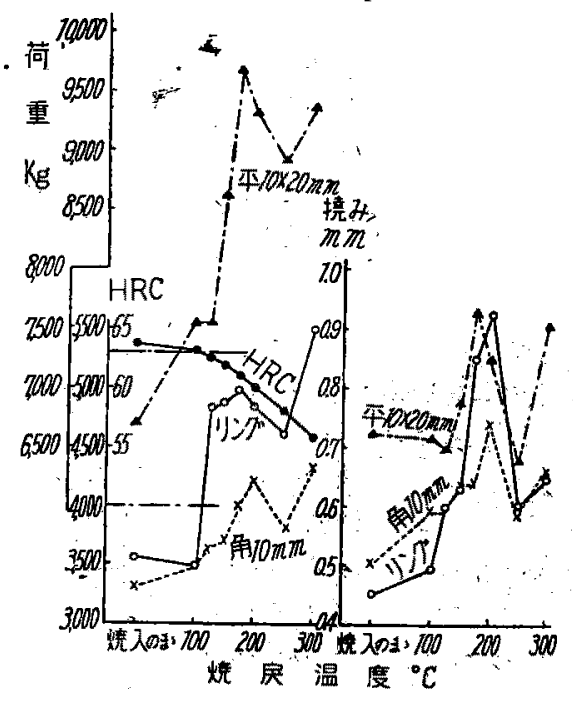

第 3 圆

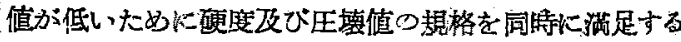
獍入温度は存在しない。

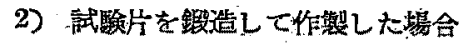

No.4 を一旦 $\$ 50 \mathrm{~mm}$ 亿鏗伸し，次に外径 $85 \times$ 肉径 $55 \times$ 高さ $30 \mathrm{~mm}$ ○ング及び平 $15 \times 25 \times$ 曼さ $55 \mathrm{~mm}$

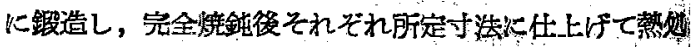
理した。

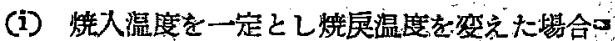

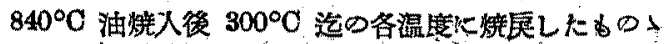
試験結果を第 3 図に示す。これによれば HRO 63 以上 を示すのは概七七㜔戻温度 $125 \circ \mathrm{C}$.

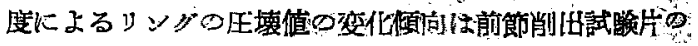


埸合と類似しているが，鉔造試験片では压壦值が大きい

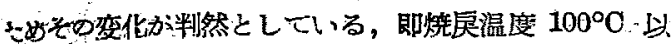
下で 3,000 3,500kg でるが $125^{\circ} \mathrm{C}$ で急增して

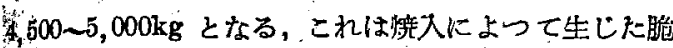

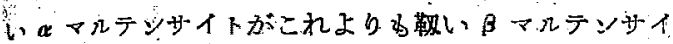

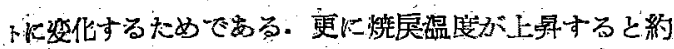
$250^{\circ} \mathrm{C}$ 附近に括いで生填値む少しく低下主るがこれは残

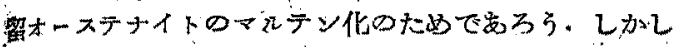

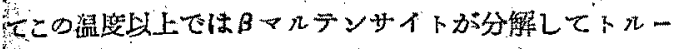

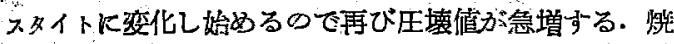

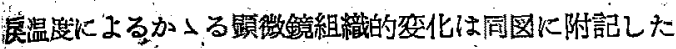

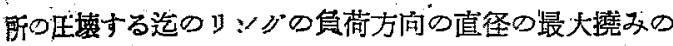

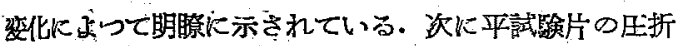

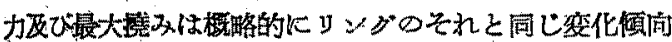
を示している゙、とれによればリングの硬度 HRO 63 以 上殴壊值 $4,000 \mathrm{~kg}$ に対店すべき平試験片の圧折力は不

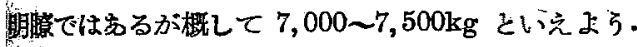

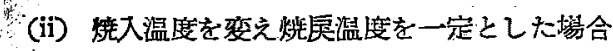

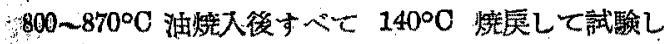

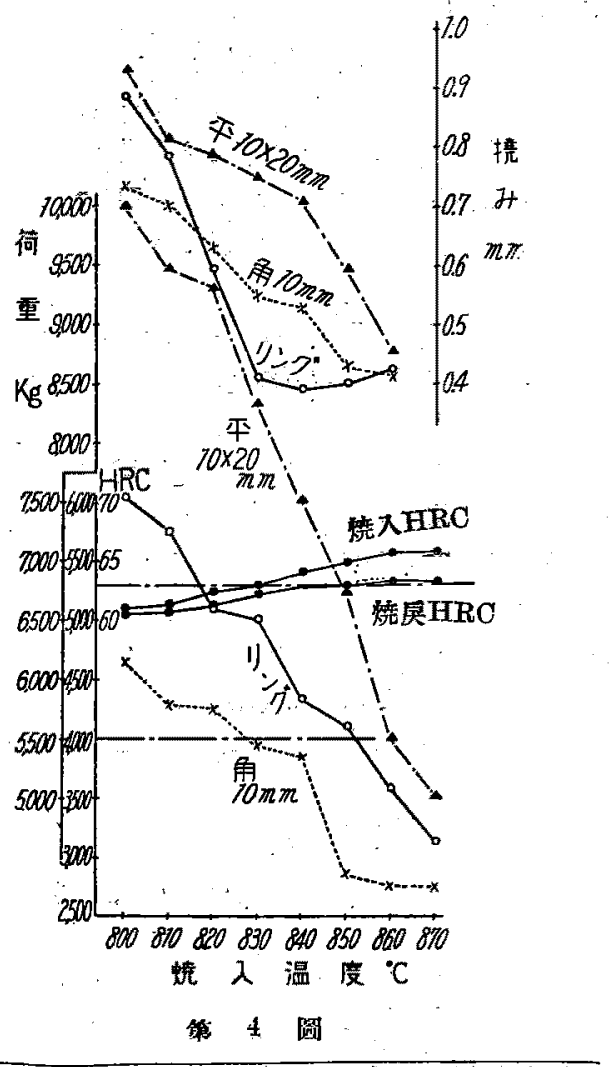

I）出口，須賀，本誈，37(昭 26), 663

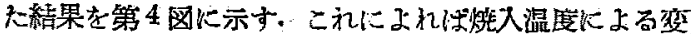

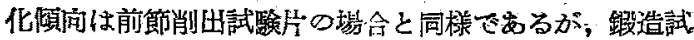

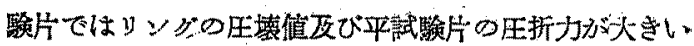

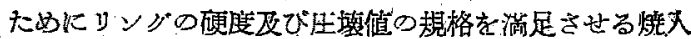
温症としては辛らじて $850^{\circ} \mathrm{C}$ が存在することになる。

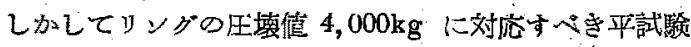
片の在折力は約 $6,500 \sim 7000 \mathrm{~kg}$ といるよら。

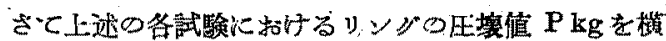

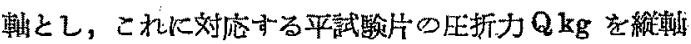

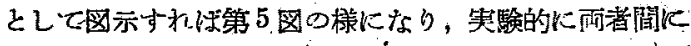
直舶的関保が成立する。

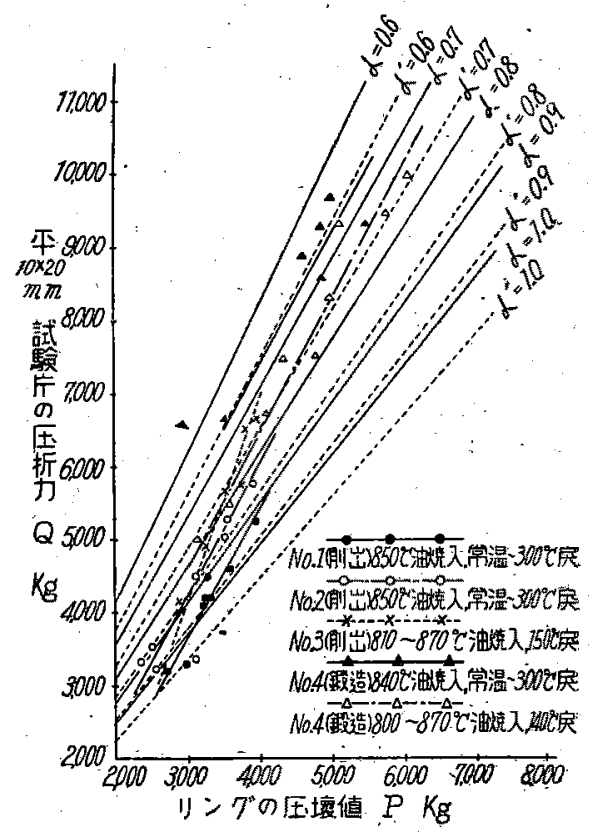

第 5 满

3) 琶都的考察

いまリングと平試験片とが共に闰じ弾性体であるとす オい゙， $\mathbf{P} \mathbf{Q}$ との間には理論的にむる関俰式が存在する はずである・次にこれを求めて見よう。

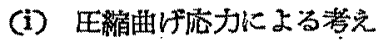

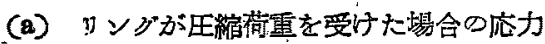

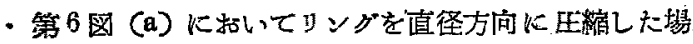

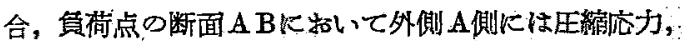
内側B側には引張応力が作朋する・しかしてこれらの店

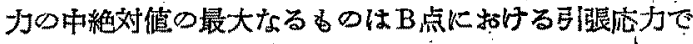

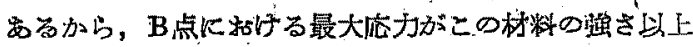

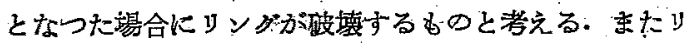

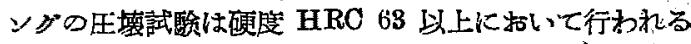




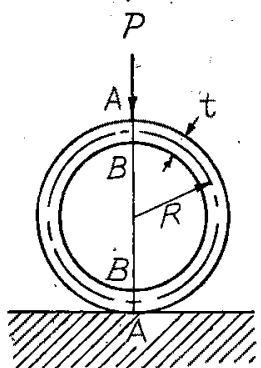

(a)

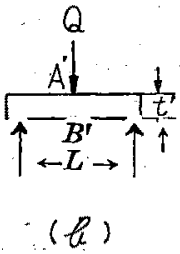

第 6 澶

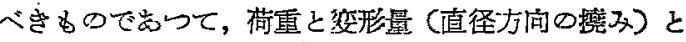
は概して直䠌的岢化をなし塑性变形は汪とにど起らずし

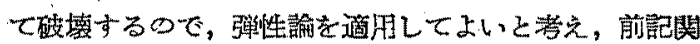
係式を求を机次の通りでるる。

$$
\begin{aligned}
& \mathrm{R}=\text { り : グの平均半径 } \\
& \mathrm{t}=\text { 泀上肉厚 } \\
& l=\text { 同上高さ } \\
& A=\text { 同上断面稳 }=\mathrm{t} l \\
& \mathrm{r}=\text { 中立面曲揫半径 }
\end{aligned}
$$

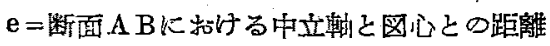

$$
\begin{aligned}
& =\mathrm{R}-\mathrm{r} \\
& =R\left(1-\frac{1}{1+\lambda}\right)
\end{aligned}
$$

但L $\lambda=-\frac{1}{3}\left(\frac{\mathrm{t} / 2}{\mathrm{R}}\right)^{2}+\frac{1}{5}\left(\frac{\mathrm{t} / 2}{\mathrm{R}}\right)^{4}+\cdots \cdots \cdots$

$$
\begin{aligned}
& \mathrm{M}=\text { 断面 } \mathrm{AB} \text { Bの曲げモーメ゙ント } \\
& \therefore=\frac{\mathrm{PR}}{\pi}
\end{aligned}
$$

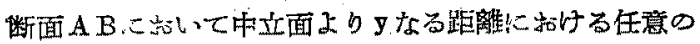

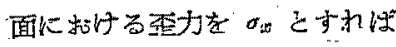

$$
\sigma_{t}=\frac{\mathrm{My}}{\mathrm{Ae}(\mathrm{r}-\overline{\mathrm{y}})}=\frac{\mathrm{PRy}}{\pi \mathrm{Ae}(\mathrm{R}-\mathrm{e}-\mathrm{y})}
$$

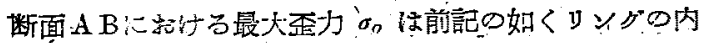
側○B点に生ずるから

$$
\begin{aligned}
\sigma_{0}=\left(\sigma_{x}\right) & t=\frac{\mathrm{PR}\left(-\frac{\mathrm{t}}{2}-\mathrm{e}\right)}{\pi \mathrm{Ae}\left(\mathrm{R}-\frac{\mathrm{t}}{2}\right)} \\
& =\frac{\mathrm{PR}\left\{\frac{\mathrm{t}}{2}-\mathrm{R}\left(1-\frac{1}{1+\lambda}\right)\right\}}{\pi \mathrm{AR}\left(1-\frac{1}{1+\lambda}\right)\left(\mathrm{R}-\frac{\mathrm{t}}{2}\right)}
\end{aligned}
$$

$$
=\frac{P}{\pi A}\left\{\frac{\frac{t}{2}}{\lambda\left(R-\frac{t}{2}\right)}-1\right\}
$$

(b) 平試験片が集中荷重を受けた埸合の応力

前指第 6 国 (b) において平訝験片

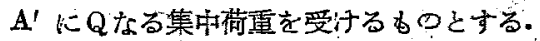

$$
\begin{aligned}
& \mathbf{t}^{\prime}=\text { 平試騒片厚さ } \\
& l=\text { 信 }
\end{aligned}
$$

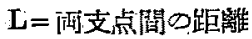

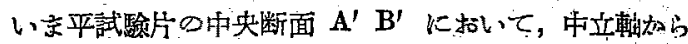

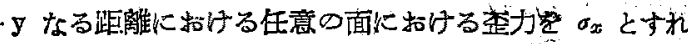

ば $\quad \sigma_{x^{\prime}}{ }^{\prime}=\frac{3 \mathrm{QL}}{l_{\mathrm{t}^{\prime 3}}^{\prime 3}} \mathrm{y}$

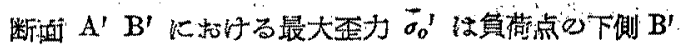
点に生ずるから

$$
\sigma_{0}^{\prime}=\frac{3 \mathrm{QL}}{l_{\mathrm{t}^{\prime 3}}^{\prime}}-\frac{\mathrm{t}^{\prime}}{2}=\frac{3}{2} \frac{\mathrm{QL}}{l^{\prime} \mathrm{t}^{\prime 2}}
$$

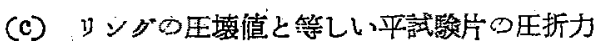

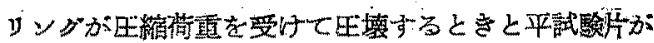
集中荷垔を受けて区折するときに

$$
\sigma_{0}=\sigma_{o} \text {. }
$$

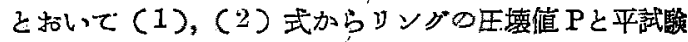

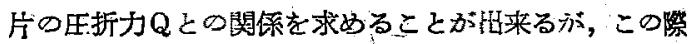

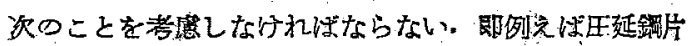

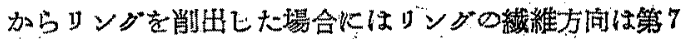

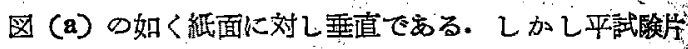

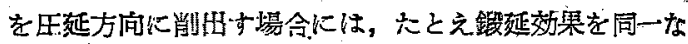

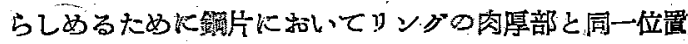
より削出したをしてb，䋊維方向は同図（b）の如く紙

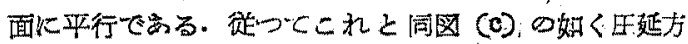

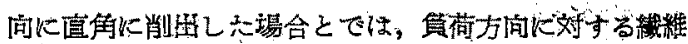

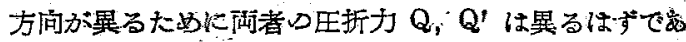

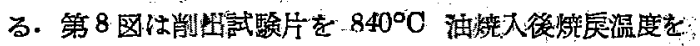

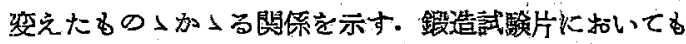

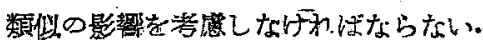

2) 柏原E

$$
\sigma_{o}=\frac{6 \mathrm{PR}}{\pi \mathrm{t}^{2}}\left(1+\frac{\mathrm{t}}{3 \mathrm{R}}\right)
$$

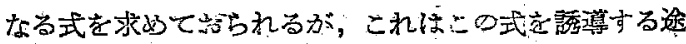
中に格いて

$$
\lambda=\frac{1}{3}\left(\frac{t / 2}{R}\right)^{2}
$$

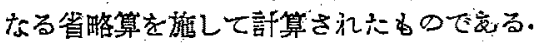

3) 践と鋗, 29 (昭 18), 719 


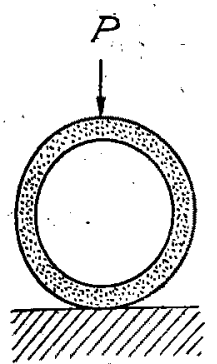

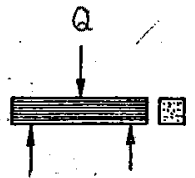

(b)

$(a)$

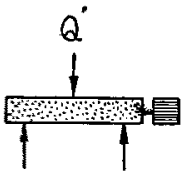

(C)
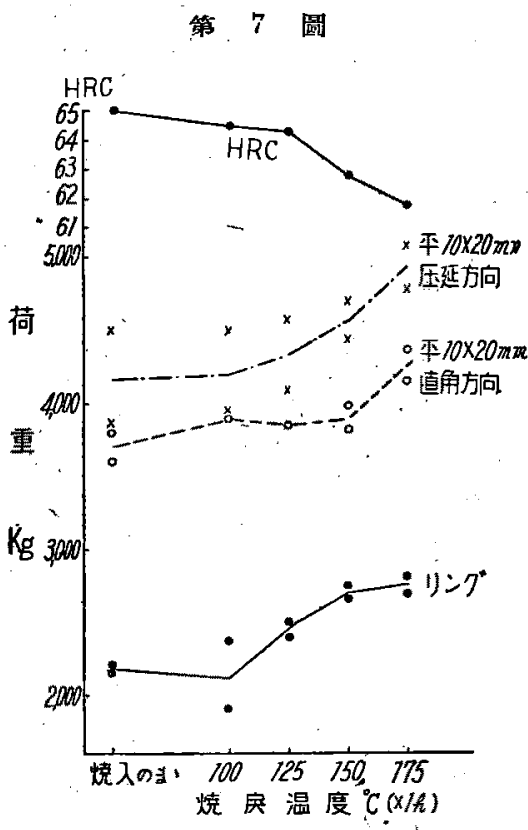

第 8 圖

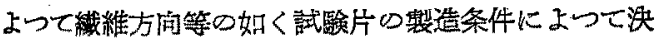

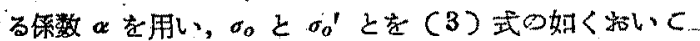
(1)，(2)式より $\mathrm{P}$ と $\mathbf{Q}$ と関係を求をれは。$$
\text { 即 } \frac{\mathbf{P}}{\pi \mathrm{A}}\left\{\frac{\frac{\mathrm{t}}{2}}{\left.\lambda_{i}^{\prime} \mathrm{R}-\frac{\mathrm{t}}{2}\right)}-1\right\}=\frac{3}{2} \frac{\mathrm{QL}}{l} \mathrm{~L}^{\prime 2} \alpha
$$$$
t=l^{\prime}, \mathrm{t}=\mathrm{t}^{\prime} \text { ととれば }
$$

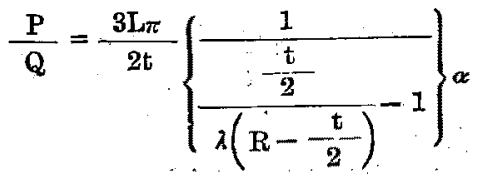

前述の各試䅷に括いでは $\mathrm{L}=40 \mathrm{~mm}, R=35 \mathrm{~mm}, t=10$ mm.であるから

$$
\frac{\mathrm{P}}{\mathrm{Q}} \doteqdot 0.806 \boldsymbol{\alpha}
$$

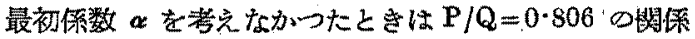
は実測値とかけ離わていたので，むしろ理猃式には全然

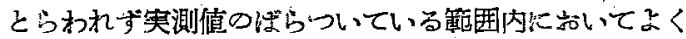
岕ては妾るぺき実験式

$$
\mathrm{Q}=1.97 \mathrm{P}-1556
$$

を立てたので岁るが，これは理論式を实測值に適胞する

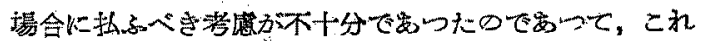

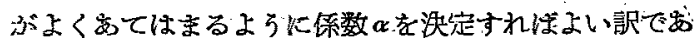
る. いま(5)式化い它 $\alpha=1,0.9,0.8,0.7,0.6$

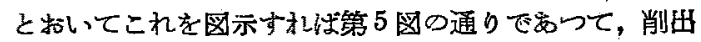

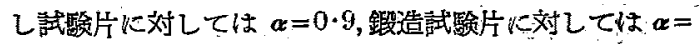
0.7 ととればよいことが分る.

(d) 抵抗線式歪計による你数 $\alpha$ の検討

上記したところでは保数 $\alpha$ は，理論式引 $\mathrm{P}, \mathrm{Q}$ の央

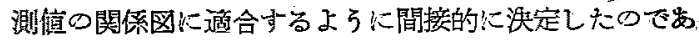

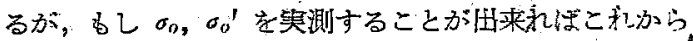

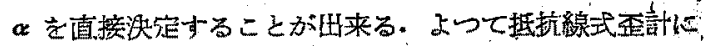
よ心て $\sigma_{0}, \sigma_{o}{ }^{r}$ を笑測し太.

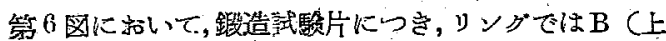
下2ク所)，平試験片では B'K， Strain gauge を筫荷

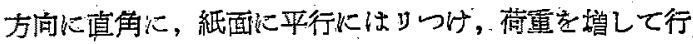

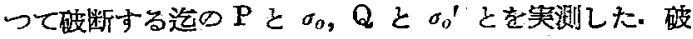
断衡雷の徝を例示すれ焉

1) У グ $\mathrm{P}=3,960 \mathrm{~kg} \quad \sigma_{o}=106 \mathrm{~kg} / \mathrm{mm}^{2}$

平試験片 $Q=0,380 \mathrm{~kg} \quad \sigma_{o}^{\prime}=144 \mathrm{~kg} / \mathrm{m}^{2} \mathrm{~m}^{2}$

$$
\therefore \quad \alpha=\frac{\sigma_{\theta}}{\sigma_{\theta}{ }^{t}}=\frac{106}{144} \doteqdot 0.75
$$

y) : グ $\mathrm{P}=3,480 \mathrm{~kg} \quad \sigma_{o}=91 \cdot 2 \mathrm{~kg} / \mathrm{mm}^{2}$ 平試驗片 $Q=4,980 \mathrm{~kg} \quad \sigma_{\theta}^{\prime}=119 \mathrm{~kg} / \mathrm{mm}^{2}$

$$
\therefore \quad \alpha=\frac{91 \cdot 2}{119 \cdot 0} \fallingdotseq 0 \cdot 77
$$

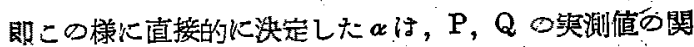
係図に適合けるよらに間接的儿決定した $\alpha$ 近い值を示 t.

(ii) 变形エネルギーによる淡え

规格では生溹試驗を行うリングの硬庭は HRO 63 以 上と規定されているが实際には硬度がこれよりす低い場 合があり，破壊に際してる若羊塑性变形を伴らと思われ

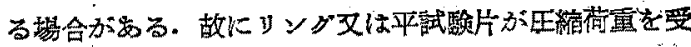

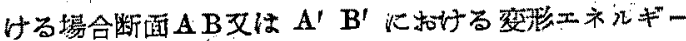
が岁る值以上とならた場合に破断すると考光た方ぶよろ

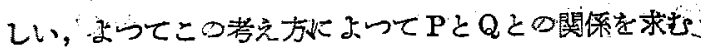


扎は次の通りでする。

(a) ツングが王縮荷重を受けた墱合ひ变形土ネルギー

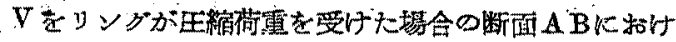

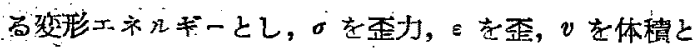
牙礼保:

$$
\mathrm{V}=\iiint \frac{1}{2} \sigma \varepsilon \mathrm{d} v
$$

但し $\sigma=\mathbf{E} \varepsilon$ とし， $\mathbf{x}$ 方向 (网居方间) には単位長さの

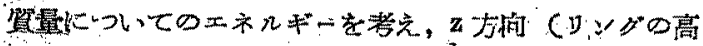

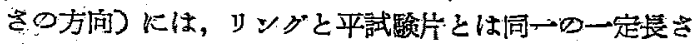

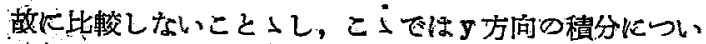
て゚み考えれは

$$
V=\frac{l}{2 \mathrm{E}} \int_{-(t / 2+\theta)}^{\mathrm{t} / 2-\theta} \sigma_{x^{2}}^{2} \mathrm{dy}
$$

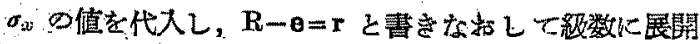

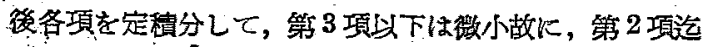
をとつて整備すれば

$$
\begin{aligned}
& \mathrm{V}=\frac{l \mathrm{P}^{2} \mathrm{R}^{2}}{2 \mathrm{EA^{2 } \pi ^ { 2 } \mathrm { e } ^ { 2 }}} \int_{-(\mathrm{t} / 2+\mathrm{\theta} ;}^{\mathrm{t} / 2-\mathrm{e}} \frac{\mathrm{y}^{2}}{(\mathrm{R}-\mathrm{e}-\mathrm{J})^{2}} \mathrm{dy} \\
& =\frac{l \mathrm{P}^{2} R^{2}}{2 E A^{2} \pi^{2} \mathrm{e}^{2}} \int_{-(\mathrm{t} / 2+\theta)}^{t / 2-e}\left(\frac{\mathrm{y}^{2}}{\mathrm{r}^{2}}+\frac{2}{\mathrm{r}^{3}} \mathrm{y}^{3}\right. \\
& \left.+\frac{3}{r^{4}} y^{4}+\cdots \cdots\right) d y \\
& =\frac{P^{2} R^{2}}{2 E l t^{2} \pi^{2} e^{2}}\left[\frac{r}{3}\left(\frac{y}{r}\right)^{3}\right. \\
& \left.+\frac{2 x}{4}\left(\frac{y}{r}\right)^{4}+\frac{3 r}{5}\left(\frac{y}{r}\right)^{5}+\cdots\right]_{-(t / 2+e)}^{t / 2-\theta} \\
& \div \frac{\mathrm{P}^{2}}{2 \mathrm{E} / \mathrm{t}^{2} \pi^{2}} \frac{(1+\lambda)^{2}}{\lambda^{2}}\left\{\frac{\mathrm{t}^{3}(1+\lambda)^{2}}{2 \mathrm{R}^{2}}\left(\frac{1}{6}-\lambda\right)\right. \\
& \left.+\lambda^{2} t(1-2 \lambda)\right\}
\end{aligned}
$$

（b）开試駼片が曲け倚重を受けた境合の交形土ネル 乎一

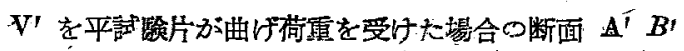
に新ける変形エれギーとすれ深

$$
\begin{aligned}
\dot{V^{\prime}} & =\frac{l^{\prime}}{2 \mathrm{E}} \int_{-\mathrm{t} / 2}^{\mathrm{t} / 2} \sigma_{x^{2}} \mathrm{dy} \\
& =\frac{l^{\prime}}{2 \mathrm{E}}\left(\frac{3 \mathrm{Q} L}{l^{\prime} t^{\prime 3}}\right)^{2} \int_{-t / 2}^{\mathrm{t} / 2} \mathrm{y}^{2} \mathrm{dy} \\
& =\frac{9 \mathrm{Q}^{2} \mathrm{~L}^{2}}{24 \mathrm{E} l^{\prime} \mathrm{t}^{\prime 3}}
\end{aligned}
$$

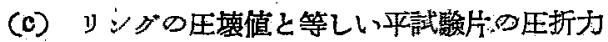

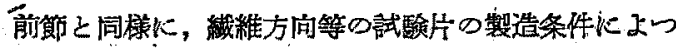

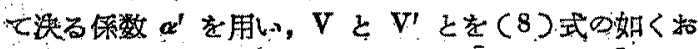

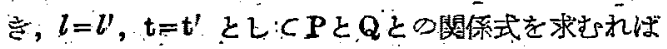

$$
\mathrm{V}=\boldsymbol{\alpha}^{\prime 2} \mathrm{~V}^{\prime}
$$

$\frac{\mathrm{P}}{\mathrm{Q}}=\frac{\mathrm{L} \pi \lambda \mathrm{R}}{(1+\lambda) \mathrm{t}} \sqrt{2\left(\mathrm{t}^{2}(1+\lambda)^{2}(1 / 6-\lambda)+2 \lambda^{2} \mathrm{R}^{2}(1-2 \lambda)^{\alpha^{\prime}}\right.}$

L， R，t D数值を代入すれ代

$$
\frac{\mathrm{P}}{\mathrm{Q}}=0.890 \alpha
$$

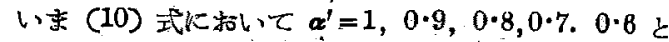

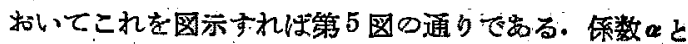

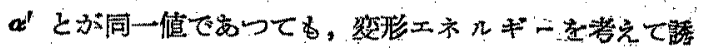
递した関係式の方が若干 P軸側に傾いている.

(iii) リングの圧壊值と庐試験片の压折力との一般的： 関俰

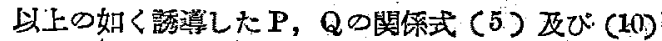

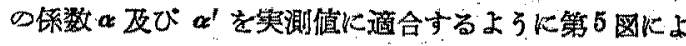

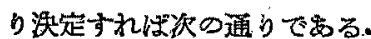

(a) 削由試験片では

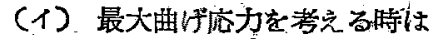

$$
\alpha=0.9 \therefore \mathrm{P}=0.7254 \mathrm{Q}
$$

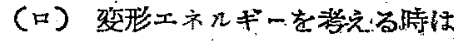
$\alpha^{\prime}=0.8 \quad \therefore \quad P=0.7120 Q$

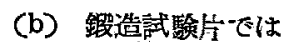

(イ）最大曲げ度力を゙考える㬨は $\alpha=0.7 \quad \therefore \quad P=0.5642 Q$

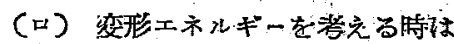
$\alpha^{\prime}=0.85 \quad \therefore \quad P=0.5785 Q$

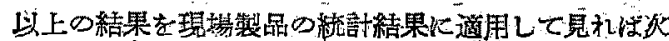
の通りである. 即第日函は約 110 チャーシの製品鈿㸝长

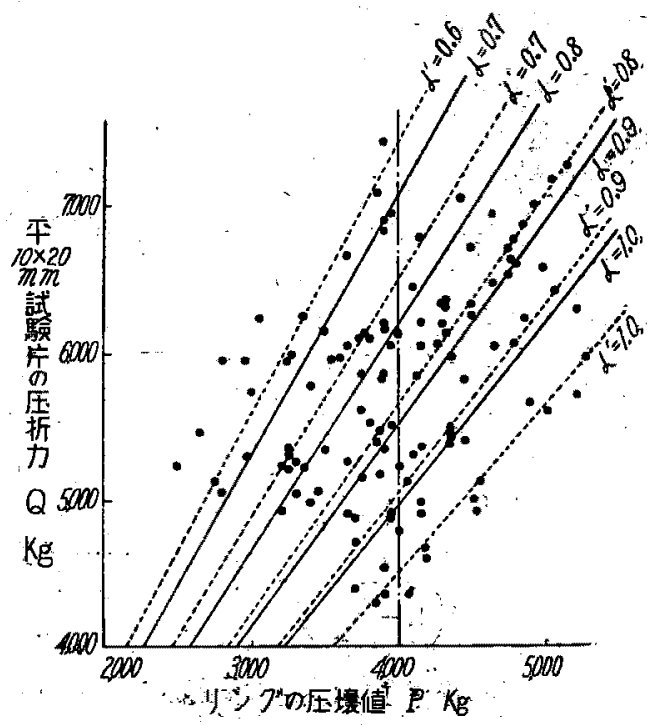

经 9.署 


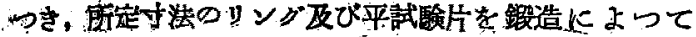

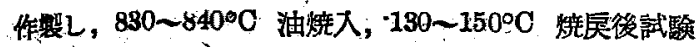

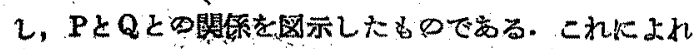
怕相当点がばらついているか，これに対てては ๙'穴0.75 ととるのが適当であつて, 前記の如き唯 1 チ

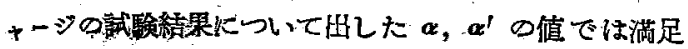
しないこをを知る・な捎削出試駼片については更に点が

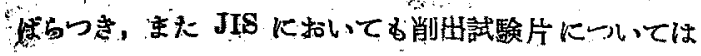

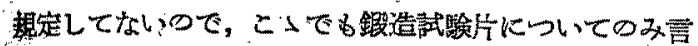
及する以止める.

$$
\begin{array}{ll}
\alpha=0.85 & P=0.6851 Q \\
\alpha^{\prime}=0.75 & P=0.6675 Q
\end{array}
$$

れり $\mathrm{P}=0 \cdot 6763 \mathrm{Q}$ ととれば

$$
P=4,000 \mathrm{~kg} \text { に詨してては } Q=5,916 \mathrm{~kg} \div 6,000 \mathrm{~kg}
$$

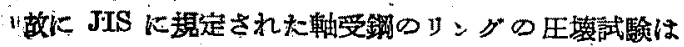
加つる試験が必要ならばこれを更に簡単なる平10×20x

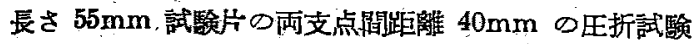
飞置換し，その压折力の規格は $6,000 \mathrm{~kg}$ 以上とするこ とを提唱する。

\section{V. リングの寸法と堅壤值との關係}

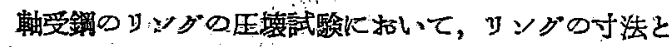

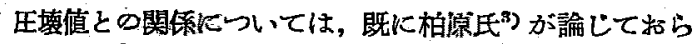
れるので, こっては单に (1) 式に先いて柏原氏の如く $\sigma_{a}=148 \mathrm{~kg} / \mathrm{mm}^{2}$ と括き，肉厚 $10 \mathrm{~mm}$ 一定とした場合.

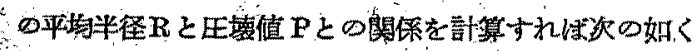

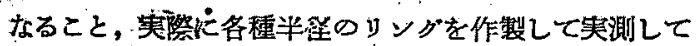

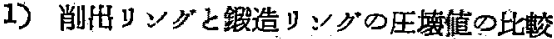

第1表 $N o .6 \oplus \$ 135 \mathrm{~mm}$ 压延材（完全焼鈍）小り，

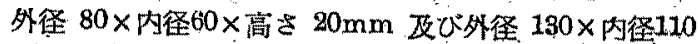

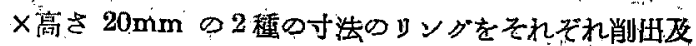

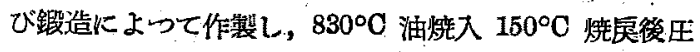

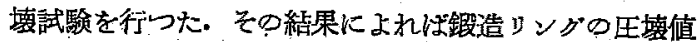

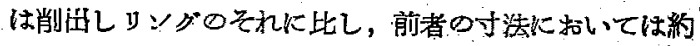
19\%,後者の寸法比いては約 10\% 大なる值を示した。

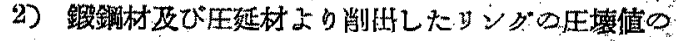
比輘

第1婊 No.7〜12 の如く異るテヤーシにつき実驗し た結果は省略し, No.13につき行つた比䫒試駼結果は次

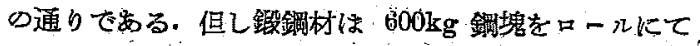

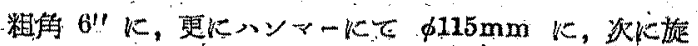

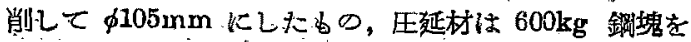
ロールにて $\phi 125 \mathrm{~mm} k$ ，これを旋削して $\phi 115 \mathrm{~mm} k$

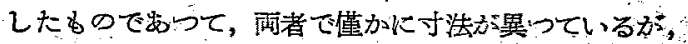

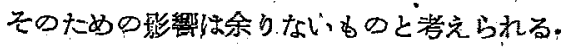

雨者のマク口組織を比輘するとデンドライトの粗細と 関してはこの場合は大䇪がないが，中心部の，Porosity

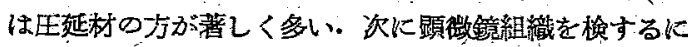
匤延材では断面の的心部は勿論半径の中央部附近におい てる Pin hole が多いが，銀鋏材に括いては断面の中心 部に僅かに認められるのみである・しかしこのだャージ

\begin{tabular}{|c|c|c|c|c|c|c|c|c|c|c|}
\hline 季均牛徑 Rmm & 15 & 20 & 25 & 30 & 35 & 40 & 45 & 50 & 55 & 60 、 \\
\hline 外牛徑 $\mathbf{m m}$ & 40 & 50 . & 60 & 70 & 80 & 90 & 100 & 110 & 120 & 190 \\
\hline 央牛徑 $\mathrm{mm}$ & 20 & 30 & 40 & 50 & 60 & 70 & 80 & 90 & 100 & 110 \\
\hline 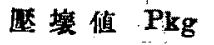 & 7440 & 6200 & 5230 & $4480^{\circ}$ & 3975 & 3510 & 3150 & 2850 & 2675 & 2430 \\
\hline
\end{tabular}
はC量が嵪いためか粗大㟶化物め析出が著しく，銅片の

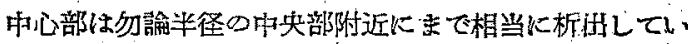

見ると，その絶対值は理論計睢值よりかなり低いチャー

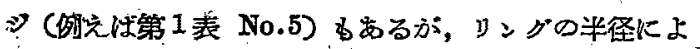

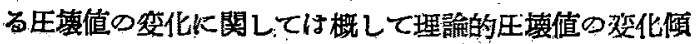
泊に近似していることを附記するに止める。

孔かし前住述へた Strain gauge Kよる测定值が相当 ばらついているのです分る如く，。老幾何にとるかに

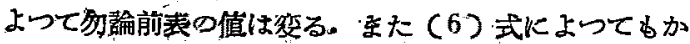

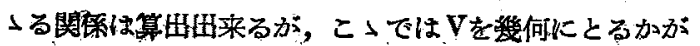

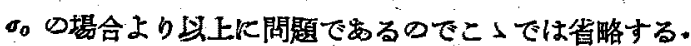

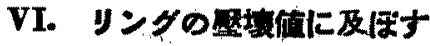

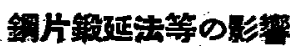

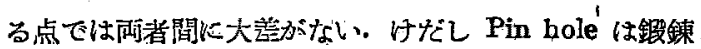
によつて相当に压閉されてあ，粗大崖化物は粗角 $6^{\prime \prime}$ が

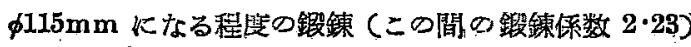
勃果では余り影留を受けないるのを者方られる. これら

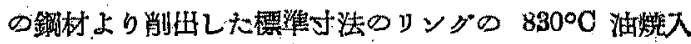

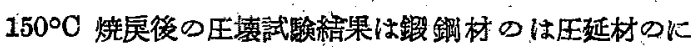
比し約 18\% 大で㐫り，その他のうャージの試験結果を 去照すれば約 10\% 以上大なることは確央であるろ。

3) 水立穖比古粗延の影㗽

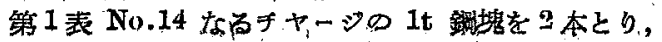
1 本は $2,000 \mathrm{t}$ 水生機“粗角 $81 / \mathrm{2}^{\prime \prime}$ K粗延後， $8150 \mathrm{~mm}$

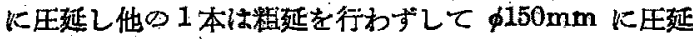

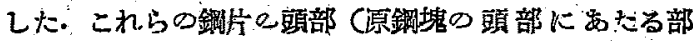


分つ、部，底部よりマクロ試験片を划㑬ててクロ組織 を比较したところ，䊒延によりマタロ組樴はかなり微細

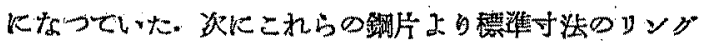

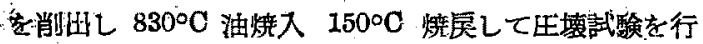
らた結果によれば，庄堎值は相当不䫏則にちらばらてい るが;概略的には粗延したるのは，しないるのに比し数\%

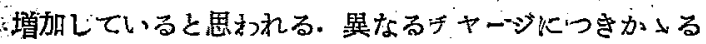

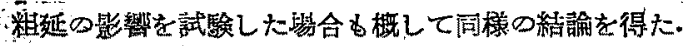

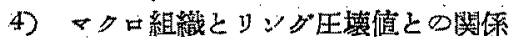

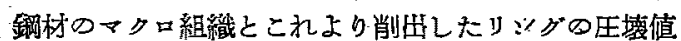
その間には関係がむりとうに思わ和数ずャージにつき試 験したが，これらではマクロ組織が罢ると同時飞他の条

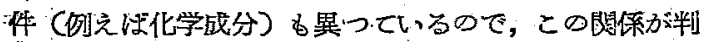

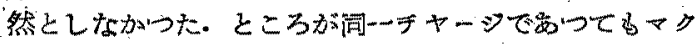

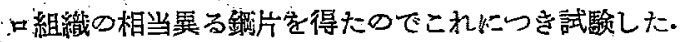

まず第1望 No.15なるチャージに括いて、・頭部 1, 中部 1 ，底部 1 及び䕱部 10 ，中部 10 ，底部 10 の 個 ○試料でマク租織及非常に異つている，即中心部の porogity とい方点では頭部 1 ，中部 10は多く，底部 1 , 頭

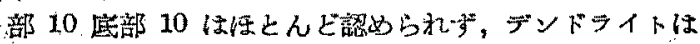
頭部 10は非常に糔く頭部 1，中部1は微細である。これ らのマク口試験残材上り外径 $125 \times$ 内径 $105 \times$ 高さ 20 m以及び外径 $80 \times$ 内径 $60 \times$ 高さ $20 \mathrm{~mm}$ ソングを削比し

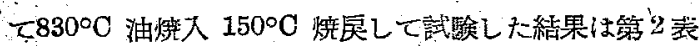

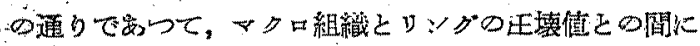
は一元的り笑係は認められながった。

第 2 表

\begin{tabular}{|c|c|c|c|c|c|}
\hline \multirow[b]{2}{*}{$\begin{array}{l}\text { No. } \\
-\end{array}$} & \multirow{2}{*}{ 位 罪 } & \multicolumn{4}{|c|}{ 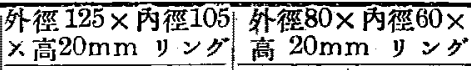 } \\
\hline & & 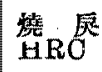 & 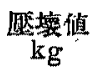 & HRO & 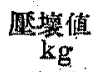 \\
\hline \multirow{6}{*}{15} & 頭部 1 . & 63.0 & 2650. & $63 \cdot 0$ & 2400 . \\
\hline & 部 1 & $63 \cdot 2$ & 1800 & $63 \cdot 9$ & 2400 \\
\hline & 底部 1 & $63 \cdot 0$ & 2300 & $63 \cdot 3$ & $\mathbf{3 3 5 0}$ \\
\hline & 頭部10 & $63 \cdot 5$ & 2000 & $63 \cdot 4$ & 2650 \\
\hline & p部10 & $63 \cdot 2$ & 1980 & 63.4 & 2300 \\
\hline & 鷹部10 & $63 \cdot 0$ & 2200 & $63 \cdot 7$ & 2600 \\
\hline
\end{tabular}

\begin{tabular}{|c|c|c|c|c|}
\hline \multirow{2}{*}{ No. } & \multirow{2}{*}{ 位政 } & \multirow{2}{*}{ 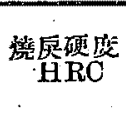 } & \multicolumn{2}{|c|}{ 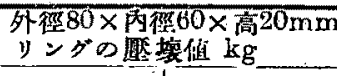 } \\
\hline & & & - 㣜定值 & 厈均。 \\
\hline \multirow{2}{*}{16} & $\begin{array}{l}\text { 頭部 } \\
1\end{array}$ & $\begin{array}{l}63 \cdot 4 \\
63 \cdot 4 \\
63 \cdot 5\end{array}$ & $\begin{array}{l}3850 \\
2950 \\
3350\end{array}$ & 3050 \\
\hline & $\begin{array}{l}\text { 喕部 } \\
23\end{array}$ & $\begin{array}{l}63 \cdot 3 \\
62 \cdot g^{\prime} \\
63 \cdot 2\end{array}$ & $\begin{array}{l}3500 \\
3650 \\
4200\end{array}$ & 3780 \\
\hline
\end{tabular}

次に No.16 火括いてては, デンドライトが副部1は細

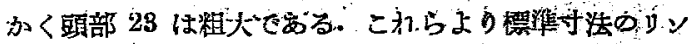

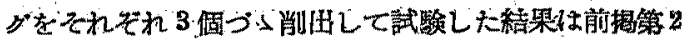
蒜に示す通りですて，デンドライトの粗大なる顽部23

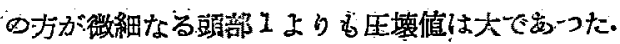

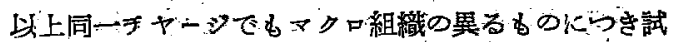
噞した結果では，マクロ組織のデンドライトの粗い，方が

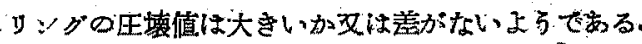

\section{VII. 總 括}

以上述べたところを総括すれは次の通りでむる.

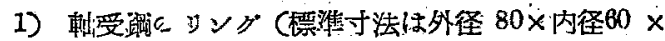
高さ $20 \mathrm{~mm}$ )の压壊試験に置換するに平詎験片の压折試

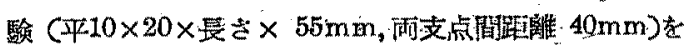
すらてする目的で，シング及び可試駼片を削出し及び鎦

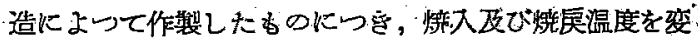

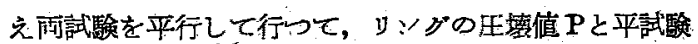

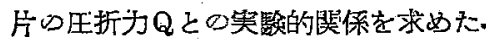

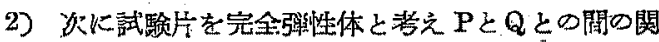

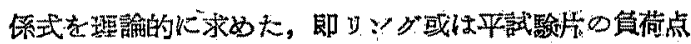
の断面に括ける最大可張応为がこの材数の强さ以上とな

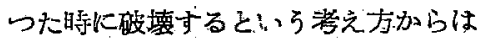

$$
\mathrm{P} / \mathrm{Q} \div 0.806 \cdot \alpha
$$

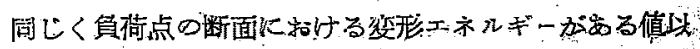

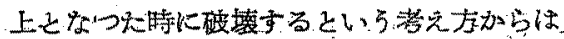

$$
\mathrm{P} / \mathrm{Q} \div 0.890 \boldsymbol{\alpha}^{\mathrm{T}}
$$

なる閣俰式を得た，但し $\alpha ， \alpha^{\prime}$ は試験片 》瀻維方向等 の妈き製造条件によつて泱る保数でる。.

3)これらの理論式が实澌值によく適合するよ5火保

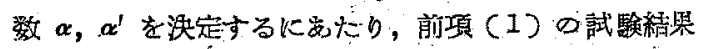

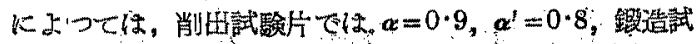

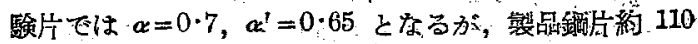

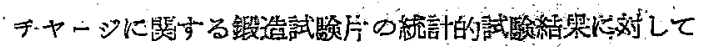

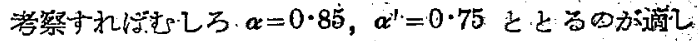
ている.・しかると焉は $\mathrm{P}=0.6763 \mathrm{Q}$ 故化 $\mathrm{P}=4,000 \mathrm{~kg}$

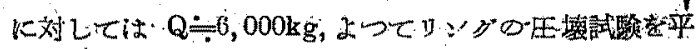

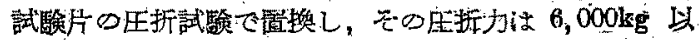
上とすることを提昆する。

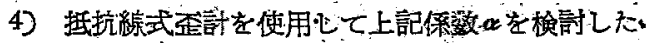

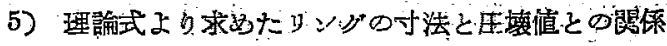

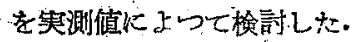

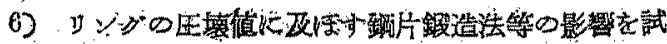

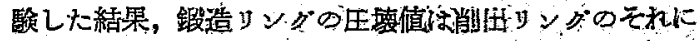

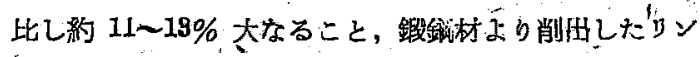


○生植値は压延材よりのそれに比し約 10〜18\% 大な

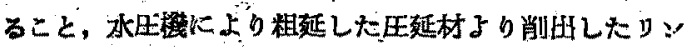

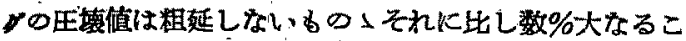
そ，同一チャータにに打いてもマクロ組織のデンドライト

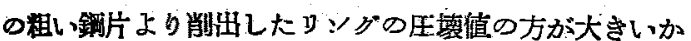
文は大崖がないことが分つた。

終りに臨み、本研究の坃表を許可きれたる大河原社長，

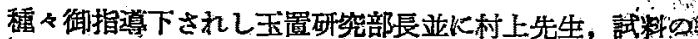

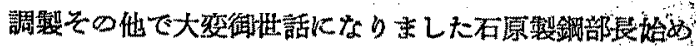

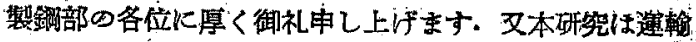

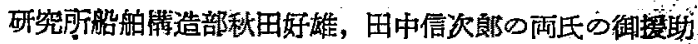
に負う所多くこつに紙上にて梁甚の謝意を表します。侗

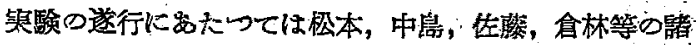
君の学を多とする次第でする（昭和 28 年 6 月寄稿)

\section{Jominy 燒入性硬度曲線に生ずる異常性について}

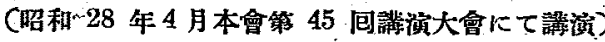

\section{河井泰 治* SOME OBSERVATIONS ON ANOMALY SHAPES OF JOMINY HARDENABILITY CURVES}

\section{Taiji Kawai}

\section{Synopșis;}

- It is usual that a Jominy hardenability curve continuously decreases its hardness as the distance from the water-cooled end increases, however, sometimes abnormal hardness reverse appears especially in Jominy curves on low alloy steels containing carbide-forming elements and also in the case of plain ligh-carbon steels. The author made a number of observations on the relation between hardenability curves and microstructures along Joming bars, and also investigated on the continuous cooling transformation and isothernial transformation diagrams of these steels. The results of observations were concluded as follows:

1. The anomaly of the hardness curve appeared both in Jominy curves and in the relation curves between hardness of isothermal decomposition products and iransformation temperatures only in the range where the intermediate transformation product and pearlite structure co-existed.

2. The hardness reverse was considered to be attributed to the discontinuity of hardness vs. transformation-temperature curves in pearlite and intermediate transformation ranges. And fine pearlite seemed rather harder than coarse bainite, although the formation temperatire of the former was higher than that of the latter.

3. Alloying of carbide forming elements such as $\mathrm{Cr}, \mathrm{V}$, Mo ete. seemed to exaggerate the anomaly probable due to their influences on the shapes of S-curves and nature of carbide in pearlite, however, it could not be considered as essential reason, because plain high carbon steels also had such tendency.

4. In the end-quenched structure of plain high-carbon steels, intermediate transformation structure was also observed as well as in the isothermal transformation structure. The author considered that the more accurate study on the S-curves of plain carbon ateels, which might, indicate pearlite and intermediate transformations separately, would enable to explain the phenomenon.

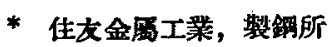

